\title{
The Impact of Computer Self Efficacy on Student Engagement and Group Satisfaction in Online Business Courses
}

\author{
Colleen Carraher Wolverton, Brandi N. Guidry Hollier and Patricia A. Lanier \\ Department of Management, B.I. Moody III College of Business Administration \\ University of Louisiana at Lafayette, Louisiana \\ wolverton@louisiana.edu \\ brandi.guidryhollier@louisiana.edu \\ patricia.lanier@louisiana.edu \\ DOI: 10.34190/EJEL.20.18.2.006
}

\begin{abstract}
As countless regional, national, and international accrediting bodies continue to employ student engagement measures as mechanisms for quality assurance, universities become more intent on achieving this important gauge of student success. Specifically, the growth in enrollment in distance learning programs adds a unique level of complexity leading researchers to search for ways to increase engagement in the online course environment. Organizations continue to value teamwork and many instructors have incorporated group work into their online courses to teach students this important skill. The present study examines the impact of student engagement on group satisfaction. Furthermore, this research places student engagement at the center of a structural equation model to determine both predictors and outcomes of this important element of student learning. Specifically, this analysis examines whether students' perceptions of computer self-efficacy impact student engagement and group satisfaction in online business courses. Our findings indicate that computer self-efficacy leads to student engagement and, further, that student engagement influences group satisfaction. Importantly, the relationship between student engagement and group satisfaction is mediated by group expectations. Discussions of findings can be utilized to understand the factors that lead to student engagement and its outcomes in online courses.
\end{abstract}

Keywords: Student engagement, online information systems courses, course design, groups, expectations, computer selfefficacy

\section{Introduction}

As many regional, national, and international accrediting bodies continue to employ student engagement measures as mechanisms for quality assurance, universities become more intent on achieving this important gauge of student success. There exists some lack of consensus in the literature regarding the conceptualization of this multi-faceted term; however, for the purposes of this research, a definition of engagement is adopted and is reflective of the variable's complex nature. Engagement is defined as "a positive, fulfilling, work-related state of mind characterized by vigor, dedication, and absorption" (Schaufeli, et al., 2002, p.74). Student engagement is correlated with multiple measures of student success. Specifically, increased levels of student engagement have been linked to student retention (Tinto, 1975), graduation rates (Lee, 2014), classroom motivation (Flynn, 2014), and course achievement (Kuh, et al., 2006). Moreover, the growth in enrollment in distance learning programs adds a unique level of complexity to the pursuit of increased student engagement and these important learning metrics.

Online enrollments are consistently growing at a faster pace than overall enrollments in higher education, particularly in public institutions (Babson College, 2016). Specifically, the number of AACSB accredited schools offering fully online MBA programs increased 48\% from 2011 to 2016 (Nelson, 2017), and currently, more than half (283) of all AACSB-accredited business schools offer online MBA programs. Unfortunately, despite the continued growth in demand for distance education, attrition rates are frequently $10 \%-20 \%$ higher for online courses than for traditional classroom settings (Holder, 2007; Nash, 2005). Researchers have cited issues of communication (Rausch and Crawford, 2012), isolation (Bocchi, Eastman and Swift, 2004), reduced motivation (Phipps and Merisotis, 1999; Street, 2010) as well as lack of student engagement (see, for example, Christophel, 1990; Klein, Noe and Wang, 2006) as possible reasons for these higher attrition rates. Furthermore, research indicates that sustained student engagement is a primary factor in ensuring student success in an online learning environment (Carraher Wolverton 2018; Fredrickson, 2015; Phipps and Merisotis, 1999; Street, 2010). Thus, given the accrediting bodies' mandates and the growth in online education, this study seeks to provide a better understanding of what drives student engagement and its influence on student groups in an online learning 
environment. To this end, computer self-efficacy and perceptions related to group expectations and satisfaction were examined.

\section{Literature review}

While several studies have addressed the causes of higher attrition rates in online learning contexts (see for example, Angelino, et al., 2007; Chyung, 2001; Jones, Moeeni and Ruby, 2005; Liu, et al., 2010; Schwarz and Zhu, 2015), the distance learning research stream has yet to conclude whether this can be attributed to students' perceptions of self or their work group. In other words, does a student's perceptions of their technological abilities influence their level of engagement in an online course? Furthermore, in what way does student engagement impact their perceptions related to group expectations and satisfaction in this environment?

\subsection{Computer Self-Efficacy}

This research draws upon Bandura's (1986) social cognitive theory and his conceptualization of self-efficacy, and the work of Compeau and Higgins (1995) in establishing the foundation for the use of computer self-efficacy (CSE) to represent a student's individual performance perceptions. With consideration of Bandura's theoretical model, Compeau and Higgins (1995) define CSE as "a judgment of one's capability to use a computer" (p.192), which has since been expanded into various contexts (i.e., Carraher Wolverton, et al., 2019; Dang, et al., 2016; Paradice, et al., 2018).

Researchers began studying this construct in the context of online learning environments approximately a decade ago. Lim (2001) found CSE was significantly correlated with student satisfaction in online learning. Moreover, CSE has been shown to exert a positive and significant impact on online learning readiness of students (Achukwu, et al., 2015), and a positive influence on performance expectations in blended e-learning system environments ( $\mathrm{Wu}$, Tennyson and Hsia, 2010). However, there are conflicting findings regarding the relationship between CSE and student engagement. In their 2012 study of online students, Sun and Rueda found that although situational interest and self-regulation were found to be significantly correlated with three factors of engagement (behavioral, emotional, and cognitive), CSE did not appear to be associated with any of the engagement constructs.

Contrarily, Pellas (2014) reported that CSE, metacognitive self-regulation, and self-esteem in online courses were positively correlated with several aspects of student engagement including cognitive and emotional factors. Also, learning engagement has been shown to be positively related to computer self-efficacy Chen (2017). More specifically, Laird and Kuh (2005) discovered that a higher level of computer self-efficacy is related to a higher level of information and communications technology (ICT) engagement. Finally, several studies suggest that a student's belief about their abilities related to the use of technologies is a critical factor in determining the level at which they will engage in learning environments that are technologically integrated (see, for example, Tzeng, 2009).

These contradictory findings present inconsistencies in the literature, and this study seeks to further clarify this relationship.

\subsection{Student Engagement}

As student engagement has been linked to various measures of student success (e.g., student learning and student satisfaction), evidence and examples of this construct are often required as part of the accreditation reporting process. Thus, institutions of higher learning frequently examine aspects of engagement with a focus on improving learning outcomes (Kuh, et al., 2006). In response, researchers have suggested several methods for increasing student engagement in an online setting. For instance, Nelson Laird and Kuh (2005) and Thurmond and Wambach (2004) demonstrated that collaborative work and information technology play an important role in promoting student engagement. In addition, research indicates that the use of visual programming tools (Dekhane, Xu and Tsoi, 2013), case studies (Taneja, 2014), and simulations (Riordan, Hine and Smith, 2017) improve levels of student interaction and engagement in online courses.

Additionally, generational research on the personality characteristics of our current student bodies suggests that these individuals equate their student experience with higher levels of digital engagement (Preville, 2018). Some researchers suggest that to leverage student engagement and enthusiasm, online instructors need to possess an appreciation of the differences in how students learn and the variables that contribute to these differing 
characteristics (Coy, Marino and Serianni, 2014). Therefore, online learning environments can create barriers or opportunities for student engagement based on individual student traits. Regardless of the method suggested, tool employed, or theory proposed, all researchers agree that student engagement is an important, and often elusive, objective in online learning environments.

\subsection{Group Performance Interactions}

Likewise, group activities have been found to exhibit positive outcomes in distance learning courses, such as improved performance, critical thinking, and interaction (Bliss and Lawrence, 2009). Collaborative work results in positive outcomes in online contexts, with some research reporting increased student engagement as a result of shared learning efforts (see, for example, Nelson Laird and Kuh, 2005; Robinson and Hullinger, 2008). In addition, researchers indicate that instructors often find distance learning students eager to work in teams, and instructors even experience complaints when a course does not offer adequate opportunities for group work (Williams, Duray and Reddy, 2006). Further, limiting the interaction amongst students in an online setting frequently results in feelings of isolation that may lead to attrition (Yuan and Kim, 2014). Muilenburg and Berge (2005) studied social interaction in online learning environments and found that a strong correlation exists between learning satisfaction and social interaction. Thus, employing team-based approaches to distance learning has the potential to improve levels of satisfaction, especially as student interaction increases (Williams, Duray and Reddy, 2006). Yet, it is also important for this outcome to ensure students have realistic expectations for group interactions. In fact, Zhu and Schwarz (2015) found that group expectations impact both group satisfaction and student engagement. Therefore, since extant research finds that group work is highly beneficial to the online learning experience (see, for example, Palloff and Pratt, 2005), it is essential to better understand the relationships among/between variables which impact these group interactions.

Thus, given the proven importance and often conflicting findings of these constructs, this study also seeks to determine whether a student's level of engagement directly impacts group expectations and satisfaction. This is critical, as student engagement constitutes one of the principal elements of effective instruction and effective learning in online course settings (Fredrickson, 2015). Additionally, many accrediting bodies are utilizing various measures of engagement (e.g., student, university, and community) as indicators of university effectiveness (Dostaler, Robinson and Tomberlin, 2017). Given these internal and external emphases, it is essential to further our understanding of student engagement in all classroom settings.

\section{Data collection}

We collected data from students in online business courses at a public university in the southeastern United States. The students completed the online survey for additional bonus points in their related courses.

Eighty-three students completed the survey, for a response rate of $62 \%$. According to the "10 times" rule, the sample size should be at least 10 times the number of incoming paths to the construct with the greatest number of incoming paths (Barclay, Higgins and Thompson, 1995; Chin and Newsted, 1998; Hair, Ringle and Sarstedt, 2011). Therefore, the sample size is sufficient.

Most of these respondents were female (59.6\%), with $40.4 \%$ male respondents. A slight majority of the respondents (52.6\%) were under 25 years of age. The other respondents were 30 years of age $(26.3 \%)$ or between 25 and 30 years of age (21.1\%).

\section{Measures}

The purpose of this study is to determine whether computer self-efficacy (CSE) impacts student engagement and determine its impact on group satisfaction and group expectations. Computer self-efficacy represents an individual trait regarding an individual's beliefs about their abilities to competently use computers (Compeau and Higgins, 1995). The original CSE measure from Compeau and Higgins (1995) has been adapted in multiple contexts such as post-adoptive usage (Tams, Thatcher and Craig, 2018), IS security deterrence (Paradice, et al., 2018), and online education (Carraher Wolverton, et al., 2019; Dang, et al., 2016).

We utilized group expectations and group satisfaction as dimensions of successful group interactions. The group expectations measure and the group satisfaction measure were adapted from Premkumar and Bhattacherjee (2008). Utilizing these interactional constructs, this research sought to better understand the relationships between the student's level of satisfaction with their group, their expectations about their group, and their level 
of engagement in the course. Further, the multidimensional student engagement measure from Schaufeli, et al. (2002) was used. This measure has been adapted for use in online education in extant studies (Schwarz and Zhu, 2015).

\section{Data analysis}

The first step in analyzing the measurement model involves an examination of the adequacy of the measures. Examining the individual item reliabilities, represented by their loadings to their respective construct, ensures that the items are measuring the constructs as they were designed. As Chin, Marcolin and Newsted (2003) state, "standardized loadings should be greater than 0.707" (p.325).

As some items exhibited a coefficient alpha below the .70 threshold (Nunnally, 1978), they were removed from further analysis. Thus, the analysis was able to ensure that the sampling domain had been adequately captured (Churchill, Jr., 1979) without including items that make progressively less of an impact on the reliability (Carmines and Zeller, 1979).

\section{Analysis and results}

\subsection{Data Analysis}

Data were analyzed using structural equation modeling. Given the small sample size $(n=83)$ and the corresponding lack of statistical power in utilizing a covariance-based approach (Westland, 2010), the partial least squares (PLS) approach was selected, specifically Smart PLS 3.0 (Ringle, Wende and Becker, 2015) software. We chose to utilize PLS because it provides advantages for datasets with small sample sizes (e.g., Barclay, Higgins and Thompson, 1995; Chin, Marcolin and Newsted, 2003; Chin, 1998; Gefen, Straub and Boudreau, 2000).

To test the hierarchical component model (Lohmöller, 2013), researchers employed the two-stage HCM analysis as recommended by Hair, et al. (2017) and Wetzels, Odekerken-Schröder and Van Oppen (2009). 
Table 1: Loadings and Cross-Loadings of Hierarchical Component Model

\begin{tabular}{|c|c|c|c|c|c|c|c|}
\hline & $\begin{array}{l}\text { Computer } \\
\text { Self- } \\
\text { Efficacy }\end{array}$ & $\begin{array}{l}\text { Engageme } \\
\mathrm{nt}\end{array}$ & $\begin{array}{l}\text { Engagemen } \\
\text { t- } \\
\text { Absorption }\end{array}$ & $\begin{array}{l}\text { Engagemen } \\
\text { t- } \\
\text { Dedication }\end{array}$ & $\begin{array}{l}\text { Engagemen } \\
\text { t- } \\
\text { Vigor }\end{array}$ & $\begin{array}{l}\text { Group } \\
\text { Expectatio } \\
\text { ns }\end{array}$ & $\begin{array}{l}\text { Group } \\
\text { Satisfactio } \\
\mathrm{n}\end{array}$ \\
\hline CSE_1 & 0.813 & 0.344 & 0.132 & 0.366 & 0.374 & 0.178 & 0.127 \\
\hline $\begin{array}{l}\text { CSE_1 } \\
0\end{array}$ & 0.783 & 0.297 & 0.201 & 0.297 & 0.273 & 0.225 & 0.073 \\
\hline CSE_2 & 0.795 & 0.245 & 0.138 & 0.189 & 0.313 & 0.197 & 0.030 \\
\hline CSE_3 & 0.826 & 0.393 & 0.152 & 0.363 & 0.490 & 0.156 & 0.027 \\
\hline CSE_4 & 0.760 & 0.232 & 0.194 & 0.097 & 0.346 & 0.147 & -0.053 \\
\hline CSE_7 & 0.797 & 0.373 & 0.233 & 0.383 & 0.348 & 0.420 & 0.246 \\
\hline CSE_8 & 0.772 & 0.301 & 0.055 & 0.345 & 0.343 & 0.305 & 0.039 \\
\hline $\begin{array}{l}\text { ENGA_ } \\
1\end{array}$ & 0.260 & 0.753 & 0.750 & 0.645 & 0.634 & 0.487 & 0.338 \\
\hline $\begin{array}{l}\text { ENGA_ } \\
1\end{array}$ & 0.260 & 0.753 & 0.750 & 0.645 & 0.634 & 0.487 & 0.338 \\
\hline $\begin{array}{l}\text { ENGA_ } \\
2\end{array}$ & 0.123 & 0.500 & 0.787 & 0.328 & 0.304 & 0.408 & 0.196 \\
\hline $\begin{array}{l}\text { ENGA_ } \\
2\end{array}$ & 0.123 & 0.500 & 0.787 & 0.328 & 0.304 & 0.408 & 0.196 \\
\hline $\begin{array}{l}\text { ENGA_ } \\
3\end{array}$ & 0.078 & 0.667 & 0.805 & 0.575 & 0.450 & 0.338 & 0.217 \\
\hline $\begin{array}{l}\text { ENGA_ } \\
3\end{array}$ & 0.078 & 0.667 & 0.805 & 0.575 & 0.450 & 0.338 & 0.217 \\
\hline $\begin{array}{l}\text { ENGA_ } \\
4\end{array}$ & 0.159 & 0.661 & 0.879 & 0.496 & 0.466 & 0.271 & 0.084 \\
\hline $\begin{array}{l}\text { ENGA_ } \\
4\end{array}$ & 0.159 & 0.661 & 0.879 & 0.496 & 0.466 & 0.271 & 0.084 \\
\hline $\begin{array}{l}\text { ENGD_ } \\
1\end{array}$ & 0.351 & 0.872 & 0.657 & 0.920 & 0.697 & 0.683 & 0.398 \\
\hline $\begin{array}{l}\text { ENGD_ } \\
1\end{array}$ & 0.351 & 0.872 & 0.657 & 0.920 & 0.697 & 0.683 & 0.398 \\
\hline $\begin{array}{l}\text { ENGD_ } \\
2\end{array}$ & 0.393 & 0.826 & 0.517 & 0.895 & 0.718 & 0.621 & 0.405 \\
\hline $\begin{array}{l}\text { ENGD_ } \\
2\end{array}$ & 0.393 & 0.826 & 0.517 & 0.895 & 0.718 & 0.621 & 0.405 \\
\hline $\begin{array}{l}\text { ENGD_ } \\
3\end{array}$ & 0.401 & 0.901 & 0.621 & 0.953 & 0.766 & 0.636 & 0.323 \\
\hline $\begin{array}{l}\text { ENGD_ } \\
3\end{array}$ & 0.401 & 0.901 & 0.621 & 0.953 & 0.766 & 0.636 & 0.323 \\
\hline $\begin{array}{l}\text { ENGD_ } \\
4\end{array}$ & 0.251 & 0.782 & 0.581 & 0.861 & 0.587 & 0.656 & 0.328 \\
\hline $\begin{array}{l}\text { ENGD_ } \\
4\end{array}$ & 0.251 & 0.782 & 0.581 & 0.861 & 0.587 & 0.656 & 0.328 \\
\hline $\begin{array}{l}\mathrm{ENGV}_{-} \\
\end{array}$ & 0.466 & 0.773 & 0.516 & 0.665 & 0.854 & 0.463 & 0.115 \\
\hline $\begin{array}{l}E N G V_{-} \\
1\end{array}$ & 0.466 & 0.773 & 0.516 & 0.665 & 0.854 & 0.463 & 0.115 \\
\hline
\end{tabular}




\begin{tabular}{|l|l|l|l|l|l|l|l|}
\hline $\begin{array}{l}\text { ENGV } \\
2\end{array}$ & 0.529 & 0.677 & 0.429 & 0.524 & 0.835 & 0.399 & 0.073 \\
\hline $\begin{array}{l}\text { ENGV_ } \\
2\end{array}$ & 0.529 & 0.677 & 0.429 & 0.524 & 0.835 & 0.399 & 0.073 \\
\hline $\begin{array}{l}\text { ENGV_- } \\
3\end{array}$ & 0.204 & 0.717 & 0.440 & 0.608 & 0.839 & 0.374 & 0.104 \\
\hline $\begin{array}{l}\text { ENGV_- } \\
3\end{array}$ & 0.204 & 0.717 & 0.440 & 0.608 & 0.839 & 0.374 & 0.104 \\
\hline $\begin{array}{l}\text { ENGV_- } \\
4\end{array}$ & 0.351 & 0.842 & 0.607 & 0.761 & 0.852 & 0.552 & 0.257 \\
\hline $\begin{array}{l}\text { ENGV_- } \\
4\end{array}$ & 0.351 & 0.842 & 0.607 & 0.761 & 0.852 & 0.552 & 0.257 \\
\hline $\begin{array}{l}\text { GEXP_ } \\
1\end{array}$ & 0.236 & 0.646 & 0.445 & 0.692 & 0.533 & 0.951 & 0.555 \\
\hline $\begin{array}{l}\text { GEXP_ } \\
2\end{array}$ & 0.245 & 0.603 & 0.434 & 0.624 & 0.509 & 0.947 & 0.566 \\
\hline $\begin{array}{l}\text { GEXP } \\
3\end{array}$ & 0.315 & 0.630 & 0.392 & 0.663 & 0.571 & 0.920 & 0.567 \\
\hline $\begin{array}{l}\text { GEXP } \\
4\end{array}$ & 0.320 & 0.636 & 0.450 & 0.674 & 0.524 & 0.966 & 0.697 \\
\hline $\begin{array}{l}\text { GEXP_- } \\
5\end{array}$ & 0.264 & 0.556 & 0.448 & 0.645 & 0.345 & 0.841 & 0.734 \\
\hline $\begin{array}{l}\text { GSAT_ } \\
1\end{array}$ & 0.073 & 0.287 & 0.259 & 0.353 & 0.132 & 0.643 & 0.974 \\
\hline $\begin{array}{l}\text { GSAT_ } \\
2\end{array}$ & 0.102 & 0.308 & 0.203 & 0.402 & 0.174 & 0.679 & 0.949 \\
\hline $\begin{array}{l}\text { GSAT_ } \\
3\end{array}$ & 0.072 & 0.310 & 0.265 & 0.374 & 0.165 & 0.612 & 0.958 \\
\hline $\begin{array}{l}\text { GSAT_ } \\
4\end{array}$ & 0.134 & 0.339 & 0.297 & 0.406 & 0.177 & 0.672 & 0.965 \\
\hline
\end{tabular}

\subsection{Measurement Model}

The first step in a PLS analysis is the analysis of the measurement (or outer) model. Following the procedures outlined by Wright, et al. (2012), the first step was the creation of a first-order measurement model. The analysis began by investigating the loadings and cross-loadings of all items to ensure that they each loaded on their respective constructs (see Table 2). All loadings were greater on the intended construct than on any other constructs. Consequently, upon determining that none of the items loaded higher on any construct other than the intended construct, all items were included. Next, researchers evaluated the reliability, discriminant, and convergent validity of the first-order measurement model. Utilizing the item loadings, internal composite reliability (ICR) was calculated to evaluate the measure's reliability, finding that all the dimensions exceeded the .70 threshold and were all above 0.88 (bottom of Table 2). Moreover, to estimate convergent validity, each dimension's average variance extracted (AVE)was evaluated. Utilizing the threshold value of 0.50 for AVE, the findings support convergent validity (Barclay, Higgins and Thompson, 1995).

Table 2: Loadings and Cross Loadings

\begin{tabular}{|l|l|l|l|l|l|l|}
\hline & $\begin{array}{l}\text { Computer } \\
\text { Self- } \\
\text { Efficacy }\end{array}$ & $\begin{array}{l}\text { Engagement } \\
-\end{array}$ & $\begin{array}{l}\text { Engagemen } \\
\mathrm{t}-\end{array}$ & $\begin{array}{l}\text { Engagemen } \\
\mathrm{t}-\end{array}$ & $\begin{array}{l}\text { Group } \\
\text { Expectations }\end{array}$ & $\begin{array}{l}\text { Group } \\
\text { Satisfaction }\end{array}$ \\
\hline CSE_1 & 0.849 & 0.16 & 0.33 & 0.376 & 0.008 & 0.17 \\
\hline CSE_10 & 0.815 & 0.213 & 0.234 & 0.286 & 0.09 & 0.194 \\
\hline CSE_2 & 0.835 & 0.179 & 0.216 & 0.439 & -0.021 & 0.068 \\
\hline
\end{tabular}


Colleen Carraher Wolverton, Brandi N. Guidry Hollier and Patricia A. Lanier

\begin{tabular}{|c|c|c|c|c|c|c|}
\hline CSE_3 & 0.777 & 0.14 & 0.269 & 0.523 & -0.031 & -0.05 \\
\hline CSE_4 4 & 0.82 & 0.121 & 0.129 & 0.367 & 0.018 & 0.016 \\
\hline CSE_5 & 0.712 & 0.073 & 0.145 & 0.245 & 0.256 & 0.278 \\
\hline CSE_7 & 0.719 & 0.115 & 0.245 & 0.248 & 0.301 & 0.319 \\
\hline CSE_8 & 0.754 & -0.018 & 0.11 & 0.357 & 0.124 & 0.055 \\
\hline ENGA_1 & 0.048 & 0.748 & 0.628 & 0.409 & 0.21 & 0.175 \\
\hline ENGA_2 & 0.111 & 0.796 & 0.44 & 0.333 & 0.312 & 0.248 \\
\hline ENGA_3 & 0.166 & 0.828 & 0.635 & 0.505 & 0.208 & 0.176 \\
\hline ENGA_4 & 0.218 & 0.824 & 0.511 & 0.45 & 0.164 & 0.023 \\
\hline ENGD_1 & 0.197 & 0.611 & 0.86 & 0.464 & 0.387 & 0.35 \\
\hline ENGD_2 & 0.258 & 0.599 & 0.905 & 0.601 & 0.371 & 0.259 \\
\hline ENGD_3 & 0.328 & 0.621 & 0.892 & 0.654 & 0.443 & 0.216 \\
\hline ENGD_4 & 0.157 & 0.53 & 0.704 & 0.417 & 0.205 & 0.132 \\
\hline ENGV_1 & 0.424 & 0.396 & 0.496 & 0.814 & 0.139 & 0.056 \\
\hline ENGV_2 & 0.419 & 0.424 & 0.49 & 0.817 & 0.137 & -0.05 \\
\hline ENGV_3 & 0.299 & 0.483 & 0.573 & 0.83 & 0.229 & 0.132 \\
\hline ENGV_4 & 0.413 & 0.473 & 0.562 & 0.855 & 0.205 & 0.109 \\
\hline GEXP_1 & 0.057 & 0.256 & 0.375 & 0.175 & 0.95 & 0.534 \\
\hline GEXP_2 & 0.037 & 0.212 & 0.319 & 0.185 & 0.954 & 0.536 \\
\hline GEXP_3 & 0.086 & 0.211 & 0.379 & 0.242 & 0.938 & 0.552 \\
\hline GEXP_4 & 0.155 & 0.253 & 0.416 & 0.248 & 0.952 & 0.618 \\
\hline GEXP_5 & 0.077 & 0.323 & 0.454 & 0.151 & 0.84 & 0.656 \\
\hline GSAT_1 & 0.143 & 0.257 & 0.292 & 0.09 & 0.579 & 0.943 \\
\hline GSAT_2 & 0.168 & 0.143 & 0.279 & 0.079 & 0.577 & 0.955 \\
\hline GSAT_3 & 0.109 & 0.14 & 0.239 & 0.052 & 0.604 & 0.961 \\
\hline GSAT_4 & 0.163 & 0.194 & 0.287 & 0.077 & 0.652 & 0.968 \\
\hline \multicolumn{7}{|c|}{ First Order Reliability and AVE } \\
\hline AVE & 0.619 & 0.639 & 0.712 & 0.688 & 0.86 & 0.915 \\
\hline ICR & 0.928 & 0.876 & 0.907 & 0.898 & 0.968 & 0.977 \\
\hline $\begin{array}{l}\text { Cronbach' } \\
\text { s } \\
\text { Alpha }\end{array}$ & 0.913 & 0.812 & 0.862 & 0.849 & 0.959 & 0.969 \\
\hline
\end{tabular}

Table 3:Intercorrelations of the Latent Variables for First-Order Constructs1

\begin{tabular}{|c|c|c|c|c|c|c|}
\hline & $\begin{array}{l}\text { Compute } \\
r \\
\text { Self- } \\
\text { Efficacy }\end{array}$ & $\begin{array}{l}\text { Engagement } \\
\text { - } \\
\text { Absorption }\end{array}$ & $\begin{array}{l}\text { Engagement } \\
\text { - } \\
\text { Dedication }\end{array}$ & $\begin{array}{l}\text { Engagement } \\
\text { - } \\
\text { Vigor }\end{array}$ & $\begin{array}{l}\text { Group } \\
\text { Expectation } \\
\mathrm{s}\end{array}$ & $\begin{array}{l}\text { Group } \\
\text { Satisfactio } \\
\text { n }\end{array}$ \\
\hline $\begin{array}{l}\text { Computer Self- } \\
\text { Efficacy }\end{array}$ & 0.787 & & & & & \\
\hline $\begin{array}{l}\text { Engagement- } \\
\text { Absorption }\end{array}$ & 0.284 & 0.844 & & & & \\
\hline $\begin{array}{l}\text { Engagement- } \\
\text { Dedication }\end{array}$ & 0.467 & 0.641 & 0.829 & & & \\
\hline
\end{tabular}




\begin{tabular}{|l|l|l|l|l|l|l|}
\hline Engagement-Vigor & 0.172 & 0.7 & 0.537 & 0.799 & & \\
\hline Group Expectations & 0.091 & 0.425 & 0.216 & 0.275 & 0.928 & \\
\hline Group Satisfaction & 0.152 & 0.287 & 0.078 & 0.192 & 0.632 & 0.957 \\
\hline
\end{tabular}

${ }^{1}$ Square root of the AVE on the diagonal.

Researchers then evaluated the construct's convergent and discriminant validity (Table 3). The Fornell-Larcker criterion was utilized, as suggested by Hair, et al. (2017), to assess discriminant validity. As the square root of the AVE exceeded the highest correlation with any other construct, it was concluded that there was adequate discriminant validity among the measures.

\subsection{Results}

The study's results (see Figure 1 ) indicate that computer self-efficacy (CSE) leads to student engagement ( $\beta=$ $0.350, t=3.785, p<0.001)$. Student engagement then leads to group expectations $(\beta=0.361, t=3.223, p<0.001)$, and group expectations predict group satisfaction $(\beta=0.632, t=7.280, p<0.001)$. However, student engagement does not impact group satisfaction $(\beta=-0.001, t=0.013, n s)$ directly; instead, that relationship is fully mediated by group expectations (Hair, et al., 2017; Zhao, Lynch and Chen, 2010).

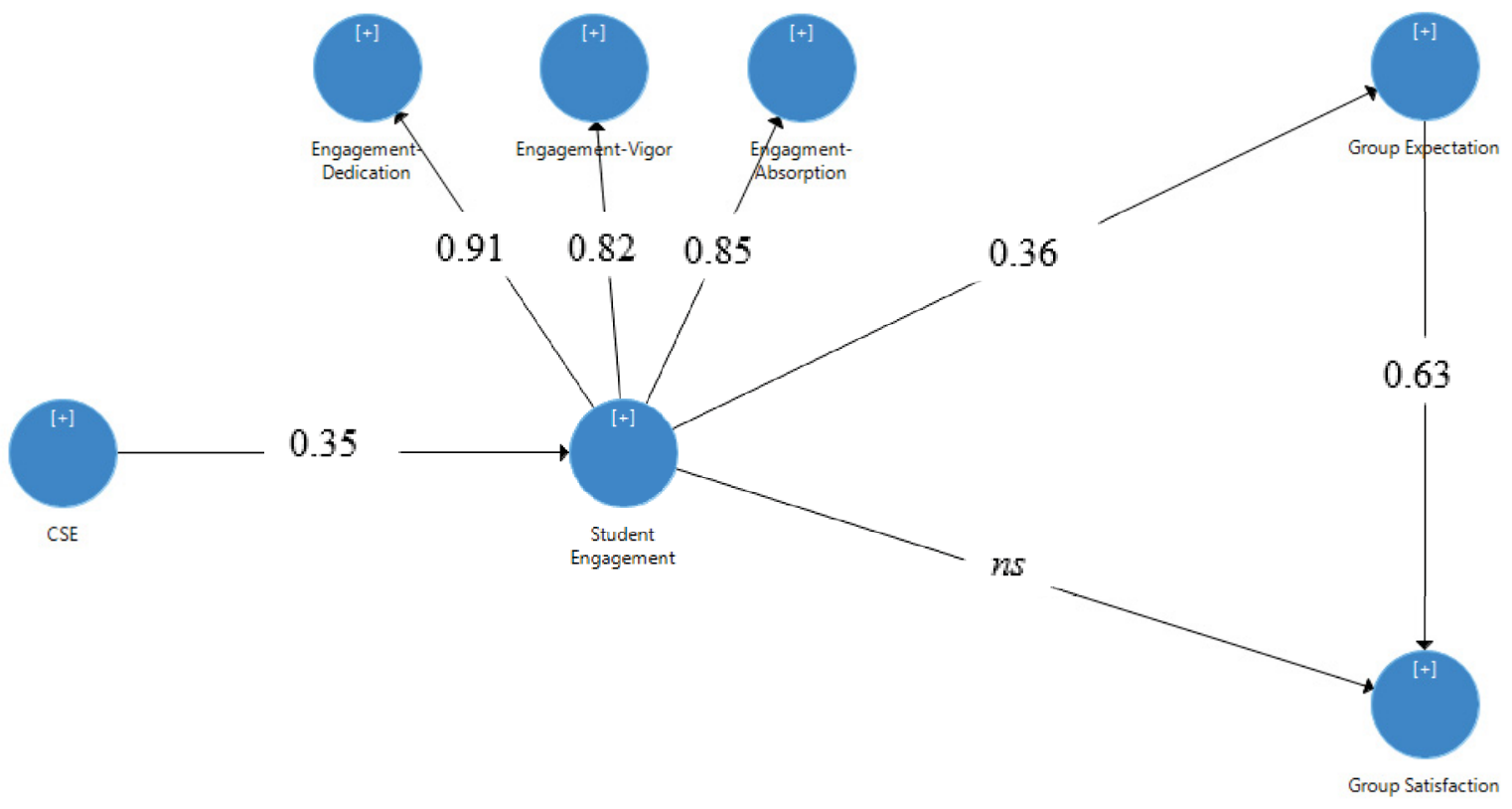

Figure 1: Results of the Structural Model

\section{Discussion}

The findings of this study indicate that student engagement is driven by a student's perception of their computer self-efficacy. This outcome evinces that a student who perceives themselves as being able to competently use computers is more likely to be engaged in an online course. Moreover, the findings also demonstrate that student engagement leads to higher levels of group satisfaction in online settings. However, this relationship is fully mediated by group expectations. Although the analysis found no direct relationship between student engagement and group satisfaction, student engagement did trigger more positive feelings about the group's ability to successfully perform.

As a result of this finding, it is recommended that instructors devote meaningful time during distance learning students' orientation to the understanding of utilized technology in order to facilitate higher levels of computer self-efficacy. However, it is not essential that students possess a mastery of technology utilized in the online learning environment. A working knowledge that establishes a comfort level would be sufficient. This would allow students to have more time to focus on course content as well as increase students' self-esteem as online learners. It follows that greater feelings of self-esteem and technological comfort could secure more active participation in group activities. Furthermore, by recognizing that group expectations mediate the relationship 
between engagement and satisfaction, an instructor should focus on increasing future expectations, or perceptions of positive future group experiences, rather than concentrating on increasing present group satisfaction. Successful learning online (or in the classroom) is supported by the creation of a community of learners (Borup, et al., 2020). Although the findings and subsequent implications of this study are insightful in offering potential ways in which instructors can increase student engagement in their online courses, the results must be viewed in light of a few limitations. Since data from a survey administered to students enrolled in an online business course was used for the purposes of this research, all information was self-reported. The results of this analysis are, therefore, subject to common method variance (Schwarz, et al., 2017). Further, a replication of this study in other settings and across disciplines is encouraged to address the issue of generalizability. Additionally, future research conducted at other universities would also aid in confirming the results of this empirical research. Because increasing our understanding of the factors that influence engagement in online settings has potentially significant implications, future research in this area is encouraged. Further, the increase in online course offerings requires further research to better understand the role of computer self-efficacy in online learning settings.

\section{Conclusion}

Student engagement remains a desired outcome in education, especially in online learning environments (Schwarz and Zhu, 2015). This study's findings indicate that engagement in online course settings is driven by a student's individual perception of their computer-related abilities. Further, our analysis found a more complex relationship exists between engagement and the group interaction factors, group expectations, and group satisfaction. Results indicate that prior or early course perceptions/expectations significantly impact the eventual course experience. Both perceptions of computer self-efficacy and group expectations are most likely determined prior to real course activity. Yet, these pre-conceived attitudes are extremely relevant for the role they play in the latter sentiments of engagement and satisfaction.

Studies have shown that computer self-efficacy improves as there are increases in the number of experiences and familiarity with technology (Lee 2015; Ozerbas and Erdogan, 2016). It naturally follows that individuals with greater exposure to different learning technologies will possess key computer competencies necessary for success in an online learning environment. Additionally, researchers suggest that accessibility to digital learning technologies has an influence on computer self-efficacy and the academic success of online students, noting a move towards improvement in higher-level skills such as problem-solving and critical thinking (see, for example, Chang, et al., 2014). Yet, students' attitudes towards online learning can also impact their levels of computer self-efficacy. For example, Prior, et al. (2016) found that students with more positive attitudes towards online learning environments also possessed more positive levels of self-efficacy. Thus, the current study's findings are consistent with those of extant literature, suggesting that greater emphasis be placed on improving students' individual technological confidence levels since computer self-efficacy is a critical component for learning content in online settings (Parkes, et al., 2015). Yet, our results also suggest that additional importance be placed on managing students' expectations specifically towards group activities. Positive pre-existing student perceptions and attitudes can significantly improve the online student's experience. Only with a clear understanding of these important constructs can instructors hope to meaningfully create engaged and satisfied students in online courses.

\section{References}

Achukwu, C. B., Nwosu, K. C., Uzoekwe, H. E. and Juliana, A., 2015. Computer self efficacy, computer-related technology dependence and on-line learning readiness of undergraduate students. International Journal of Higher Education Management, 1(2), pp.60-71.

Angelino, L. M., Williams, F. K. and Natvig, D., 2007. Strategies to engage online students and reduce attrition rates. Journal of Educators Online, [e-journal] 4(2). Available at: https://www.learntechlib.org/p/52842/ [Accessed 22 February 2020].

Babson College, 2016. Babson study: Distance education enrollment growth continues. Available at: http://www.babson.edu/news-events/babson-news/Pages/2016-babson-releases-2015-survey-of-onlinelearning.aspx [Accessed 22 February 2020].

Bandura, A., 1986. Social foundations of thought and action: a social cognitive theory. Englewood Cliffs, NJ: Prentice-Hall.

Barclay, D., Higgins, C. and Thompson, R., 1995. The partial least squares (PLS) approach to causal modeling: personal computer adoption and use as an illustration. Technology Studies, 2(2), pp.285-309.

Bliss, C. A. and Lawrence, B., 2009. From posts to patterns: A metric to characterize discussion board activity in online courses. Journal of Asynchronous Learning Networks, 13(2), 15-32. 
Bocchi, J., Eastman, J. K. and Swift, C. O., 2004. Retaining the online learner: profile of students in an online MBA program and implications for teaching them. Journal of Education for Business, 79(4), pp.245-253.

Borup, J., Graham, C.R., West, R.E., Archambault, L. and Spring, K. J., 2020. Academic Communities of Engagement: an expansive lens for examining support structures in blended and online learning. Education Technology Research and Development [e-journal]. https://doi.org/10.1007/s11423-020-09744-x

Carmines, E. G. and Zeller, R. A., 1979. Reliability and validity assessment. Sage Publications.

Carraher Wolverton, C., 2018. Utilizing synchronous discussions to create an engaged classroom in online executive education. The International Journal of Management Education, 16, pp.239-244.

Carraher Wolverton, C., Zhu, Z., Lai, G. and Benton, D., 2019. Examining the critical success factors for business analytics courses delivered through hybrid learning, Southwest Decision Sciences Institute 50th Annual Meeting, Houston, TX, 13-16 March 2019.

Chang, H., Wang, C., Lee, M., Wu, H., Liang, J., Lee, S., Chiou, G., Lo, H., Lin, J., Hsu, C., Wu, Y., Chen, S., Hwang, F. and Tsai, C., 2014. A review of features of technology-supported learning environments based on participants' perceptions. Computers in Human Behavior, 53, pp.223-237.

Chen, I.-S., 2017. Computer self-efficacy, learning performance, and the mediating rold of learning engagement. Computers in Human Behavior, 72, pp.362-370.

Chin, W. W. ed., 1998. The partial least squares approach to structural equation modeling, Volume 295. London: Psychology Press.

Chin, W. W. and Newsted, P. R. eds., 1999. Structural equation modeling analysis with small samples using partial least squares, Volume 1. Newbury Park, CA: Sage Publications.

Chin, W. W., Marcolin, B. L. and Newsted, P. R., 2003. A partial least squares latent variable modeling approach for measuring interaction effects: results from a Monte Carlo simulation study and an electronic-mail emotion/adoption study. Information Systems Research, 14(2), pp.189-217.

Christophel, D. M., 1990. The relationships among teacher immediacy behaviors, student motivation, and learning. Communication Education, 39(4), pp.323-340.

Chyung, S. Y., 2001. Systematic and systemic approaches to reducing attrition rates in online higher education. American Journal of Distance Education, 15(3), pp.36-49.

Churchill, Jr., G. A., 1979. A paradigm for developing better measures of marketing constructs. Journal of Marketing Research, 16, pp.64-73.

Compeau, D. R. and Higgins, C. A., 1995. Computer self-efficacy: Development of a measure and initial test. MIS Quarterly, 19(2), 189-211.

Coy, K., Marino, M. T. And Serianni, B., 2014. Using universal design for learning in synchronous online instruction. Journal of Special Education Technology, 29(1), pp.63-74.

Dang, Y. M., Zhang, Y. G., Ravindran, S. and Osmonbekov, T., 2016. Examining student satisfaction and gender differences in technology-supported, blended learning. Journal of Information Systems Education, 27(2), p.119.

Dekhane, S., Xu, X. and Tsoi, M. Y., 2013. Mobile app development to increase student engagement and problem solving skills. Journal of Information Systems Education, 24(4), pp.299.

Dostaler, I., Robinson, M.A. and Tomberlin, T.J., 2017. A focus on engagement: defining, measuring, and nurturing a key pillar of AACSB standards. Organization Management Journal, 14(1), pp.45-55.

Flynn, D., 2014. Baccalaureate attainment of college students at 4-year institutions as a function of student engagement behaviors: social and academic student engagement behaviors matter. Research in Higher Education, 55(5), pp.467493.

Fredrickson, J., 2015. Online learning and student engagement: Assessing the impact of a collaborative writing requirement. Academy of Educational Leadership Journal, 19(3), pp.127-140.

Gefen, D., Straub, D. and Boudreau, M.-C., 2000. Structural equation modeling and regression: Guidelines for research practice. Communications of the Association for Information Systems, 4(1), p.7.

Hair, J. F., Ringle, C. M. and Sarstedt, M., 2011. PLS-SEM: Indeed a silver bullet. Journal of Marketing Theory Practice, 19(2), pp.139-152.

Hair, J. F., Hult, G. T. M., Ringle, C. and Sarstedt, M., 2017. A primer on partial least squares structural equation modeling (PLS-SEM). Thousand Oaks, CA: Sage Publications.

Holder, B., 2007. An investigation of hope, academics, environment, and motivation as predictors of persistence in higher education online programs. The Internet and Higher Education, 10(4), pp.245-260.

Jones, K. R., Moeeni, F. and Ruby, P., 2005. Comparing Web-based content delivery and instructor-led learning in a telecommunications course. Journal of Information Systems Education, 16(3), pp. 265-272.

Klein, H. J., Noe, R. A. and Wang, C., 2006. Motivation to learn and course outcomes: the impact of delivery mode, learning goal orientation, and perceived barriers and enablers. Personnel Psychology, 59(3), pp.665-702.

Kuh, G. D., Jillian Kinzie, Buckley, J. A., Bridges, B. K. and Hayek, J. C., 2006. What matters to student success: a review of the literature. Commissioned Report for the National Symposium on Postsecondary Student Success: Spearheading a Dialog on Student Succes. Available at: https://nces.ed.gov/npec/pdf/kuh team report.pdf [Accessed 22 February 2020].

Laird, T.N. and Kuh, G., 2005. Student experiences with information technology and their relationship to other aspects of student engagement. Research in Higher Education, 46(2), pp.211-233. 
Lee, J. S., 2014. The relationship between student engagement and academic performance: Is it a myth or reality? The Journal of Educational Research, 107(3), pp.177-185.

Lee, C., 2015. Changes in self-efficacy and task value in online learning. Distance Education, 36(1), pp.59-79.

Lim, C. K., 2001. Computer self-efficacy, academic self-concept, and other predictors of satisfaction and future participation of adult distance learners. American Journal of Distance Education, 15(2), pp.41-51.

Liu, Y., Chen, H., Liu, C., Lin, C. and Chan, H., 2010. A model to evaluate the effectiveness of collaborative online learning teams-self-disclosure and social exchange theory perspective. International Journal of Cyber Society and Education, 3(2), pp.117-132.

Lohmöller, J.-B., 2013. Latent variable path modeling with partial least squares. Springer Science \& Business Media.

Muilenburg, L.Y. and Berge, Z.L., 2005. Student barriers to online learning: a factor analytic study. Distance Education, 26(1), pp.29-48.

Nash, R. D., 2005. Course completion rates among distance learners: identifying possible methods to improve retention. Online Journal of Distance Learning Administration, 8(4), pp.1-27.

Nelson, C., 2017. MBA graduates' starting salaries by professional function (Part II). AACSB, February 28. Available at:http://aacsbblogs.typepad.com/dataandresearch/mba-programs [Accessed 22 February 2020].

Nelson Laird, T. F. and Kuh, G. D., 2005. Student experiences with information technology and their relationship to other aspects of student engagement. Research in Higher Education, 46(2), pp.211-233.

Nunnally, J., 1978. Psychometric theory. New York: McGraw-Hill.

Ozerbas, M. A. and Erdogan, B. H., 2016. The effect of the digital classroom on academic success and online technologies self-efficacy. Educational Technology \& Society, 19, pp.203-212.

Palloff, R. M. and Pratt, K., 2005. Collaborating online: learning together in community. San Francisco: Jossey-Bass Inc

Paradice, D., Freeman, D., Hao, J., Lee, J. and Hall, D., 2018. A review of ethical issue considerations in the information systems research literature. Foundations and Trends ${ }^{\circledR}$ in Information Systems, 2(2), pp.117-236.

Parkes, M., Stein, S. and Reading, C., 2015. Student preparedness for university eLearning environments. Internet and Higher Education, 25, pp.1-10.

Pellas, N., 2014. The influence of computer self-efficacy, metacognitive self-regulation and self-esteem on student engagement in online learning programs: evidence from the virtual world of Second Life. Computers in Human Behavior, 35, pp.157-170.

Phipps, R. and Merisotis, J., 1999. What's the difference? a review of contemporary research on the effectiveness of distance learning in higher education. Washington, DC: The Institute for Higher Education Policy.

Premkumar, G. and Bhattacherjee, A., 2008. Explaining information technology usage: a test of competing models. Omega, 36(1), pp.64-75.

Preville, P., 2018. Furthermore, generational research on the characteristics of our current student bodies, suggest that these individuals connect their student experience with higher levels of digital engagement. Top Hat, Trends in Higher Education [blog] 16 October. Available at: https://tophat.com/blog/generation-z-teach-classroom/ [Accessed 22 February 2020].

Prior, D. D., Mazanov, J., Meacheam, D., Heaslip, G. and Hanson, J. 2016. Attitude, digital literacy and self-efficacy: flow-on effects for online learning behavior. Internet and Higher Education, 29, pp.91-97.

Rausch, D. W. and Crawford, E. K., 2012. Cohorts, communities of inquiry, and course delivery methods: UTC best practices in learning - the hybrid learning community model. The Journal of Continuing Higher Education, 60(3), pp.175-180.

Ringle, C. M., Wende, S. and Becker, J.-M., 2015. SmartPLS 3. Boenningstedt: SmartPLS GmbH. Available at: http://www.smartpls.com.

Riordan, R. J., Hine, M. J. and Smith, T.C., 2017. An integrated learning approach to teaching an undergraduate information systems course. Journal of Information Systems Education, 28(1), pp.59-69.

Robinson, C. C. and Hullinger, H., 2008. New benchmarks in higher education: student engagement in online learning. Journal of Education for Business, 84(2), pp.101-109.

Schaufeli, W. B., Salanova, M., González-Romá, V. and Bakker, A. B., 2002. The measurement of engagement and burnout: A two sample confirmatory factor analytic approach. Journal of Happiness Studies, 3(1), pp.71-92.

Schwarz, A., Rizzuto, T, Carraher-Wolverton, C., Roldán, J. and Barrera, R., 2017. Examining the impact and detection of the "urban legend" of common method bias. Data Base for Advances in Information Systems, 48(1), pp.93-119.

Schwarz, C. and Zhu, Z., 2015. The impact of student expectations in using instructional tools on student engagement: a look through the expectation disconfirmation theory lens. Journal of Information Systems Education, 26(1), p.47.

Street, H. D., 2010. Factors influencing a learner's decision to drop-out or persist in higher education distance learning. Online Journal of Distance Learning Administration, [e-journal] 13(4). Available at: https://www.learntechlib.org/p/52605/ [Accessed 22 February 2020].

Sun, J. C. Y. and Rueda, R., 2012. Situational interest, computer self-efficacy and self-regulation: their impact on student engagement in distance education. British Journal of Educational Technology, 43(2), pp.191-204.

Tams, S., Thatcher, J. B. and Craig, K., 2018. How and why trust matters in post-adoptive usage: the mediating roles of internal and external self-efficacy. The Journal of Strategic Information Systems, 27(2), pp.170-190.

Taneja, A., 2014. Teaching tip enhancing student engagement: a group case study approach. Journal of Information Systems Education, 25(3), p.181. 
Thurmond, V. and Wambach, K., 2004. Understanding interactions in distance education: a review of the literature. International Journal of Instructional Technology and Distance Learning, 1(1), pp.9-25.

Tinto, V., 1975. Dropout from higher education: a theoretical synthesis of recent research. Review of Educational Research, 45(1), pp.89-125.

Tzeng, J-Y., 2009. The impact of general and specific performance and self-efficacy on learning with comptuer-based concept mapping. Computers in Human Behavior, 25(4), pp.989-996.

Westland, J. C., 2010. Lower bounds on sample size in structural equation modeling. Electronic Commerce Research and Applications, 9(6), pp.476-487.

Wetzels, M., Odekerken-Schröder, G. and Van Oppen, C., 2009. Using PLS path modeling for assessing hierarchical construct models: guidelines and empirical illustration. MIS Quarterly, 33(1), pp.177-195.

Williams, E. A., Duray, R. and Reddy, V., 2006. Teamwork orientation, group cohesiveness, and student learning: a study of the use of teams in online distance education. Journal of Management Education, 30(4), pp.592-616.

Wright, R. T., Campbell, D. E., Thatcher, J. B. and Roberts, N., 2012. Operationalizing multidimensional constructs in structural equation modeling: recommendations for IS research. Communications of the Association for Information Systems, 30(1), pp.367-412.

Wu, J.-H., Tennyson, R. D. and Hsia, T.-L., 2010. A study of student satisfaction in a blended e-learning system environment. Computers \& Education, 55(1), pp.155-164.

Yuan, J. and Kim, C., 2014. Guidelines for facilitating the development of learning communities in online courses. Journal of Computer Assisted Learning, 30(3), pp.220-232.

Zhao, X., Lynch Jr, J. G. and Chen, Q., 2010. Reconsidering Baron and Kenny: myths and truths about mediation analysis. Journal of Consumer Research, 37(2), pp.197-206.

Zhu, Z. and Schwarz, C. 2015. The impact of student expectations in using instructional tools on student engagement: a look through the expectation disconfirmation theory lens. Journal of Information Systems Education, 26(1), pp.47-58. 


\section{Appendix - Survey Items}

\begin{tabular}{|c|c|}
\hline I believe that... & $\begin{array}{l}\text { Adapted from } \\
\text { Premkumar and } \\
\text { Bhattacherjee (2008) }\end{array}$ \\
\hline $\begin{array}{l}\text { 1. Being in a group in this class will help me better understand new course material } \\
\text { (Strongly disagree... Strongly agree). }\end{array}$ & \\
\hline $\begin{array}{l}\text { 2. Being in a group in this class will help me learn new material (Strongly } \\
\text { disagree... Strongly agree). }\end{array}$ & \\
\hline $\begin{array}{l}\text { 3. Being in a group in this class will increase my interest in the course material } \\
\text { (Strongly disagree...Strongly agree). }\end{array}$ & \\
\hline $\begin{array}{l}\text { 4. Being in a group in this class will provide me with insight into the course material } \\
\text { (Strongly disagree... Strongly agree). }\end{array}$ & \\
\hline $\begin{array}{l}\text { 5. Being in a group in this class will facilitate interesting discussions (Strongly } \\
\text { disagree...Strongly agree). }\end{array}$ & \\
\hline $\begin{array}{l}\text { Student Engagement (Utrecht Work Engagement Scale for Students) } \\
\text { From more/less after the face-to-face case study discussion }\end{array}$ & $\begin{array}{l}\text { Adapted from Schaufeli, } \\
\text { et al. (2002) }\end{array}$ \\
\hline $\begin{array}{l}\text { Vigor } \\
\text { 1. When I'm studying for this class, I feel mentally strong. } \\
\text { 2. I can continue for a very long time when I am studying for this class. } \\
\text { 3. When I study for this class, I feel like I am bursting with energy. } \\
\text { 4. When studying for this class, I feel strong and vigorous. } \\
\text { 5. When I get up in the morning, I feel like going to this class. } \\
\text { Dedication } \\
\text { 1. I find this course to be full of meaning and purpose. } \\
\text { 2. This course inspires me. } \\
\text { 3. I am enthusiastic about this course. } \\
\text { 4. I am proud of my studies in this course. } \\
\text { 5. I find the course challenging. } \\
\text { Absorption } \\
\text { 1. Time flies when I'm studying for this class. } \\
\text { 2. When I am studying for this class, I forget everything else around me. } \\
\text { 3. I feel happy when I am studying intensively for this class. } \\
\text { 4. I can get carried away by my studies for this class. }\end{array}$ & \\
\hline Computer self-efficacy & $\begin{array}{l}\text { Adapted from Compeau } \\
\text { and Higgins (1995) }\end{array}$ \\
\hline 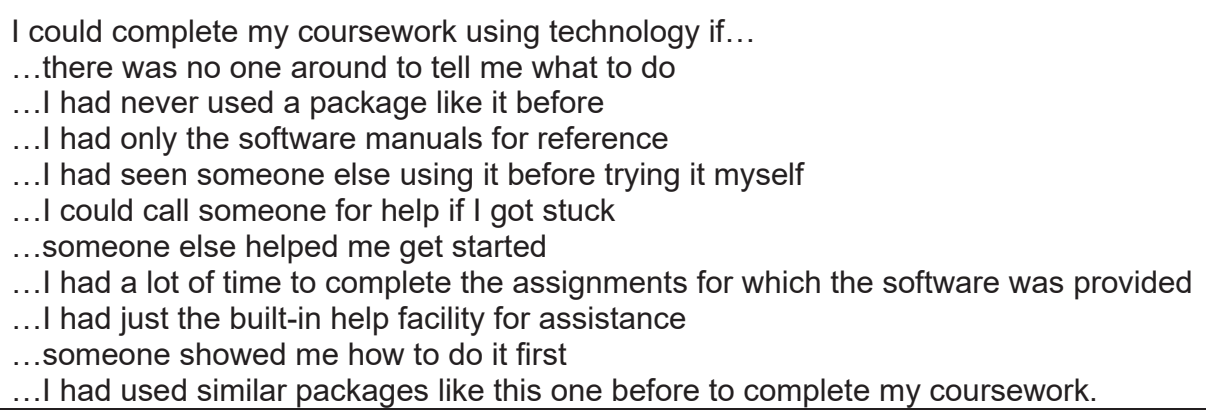 & $\begin{array}{l}\text { from not confident to } \\
\text { very confident }\end{array}$ \\
\hline
\end{tabular}


The Electronic Journal of e-Learning Volume 18 Issue 22020

\begin{tabular}{|l|l|}
\hline Group Satisfaction & $\begin{array}{l}\text { (Premkumar and } \\
\text { Bhattacherjee, 2008) }\end{array}$ \\
\hline I am _ with my group. & \\
1. Extremely displeased . . Extremely pleased. & \\
2. Extremely frustrated ... Extremely contented. & \\
3. Extremely disappointed ... Extremely delighted. & \\
4. Extremely dissatisfied ... Extremely satisfied. & \\
\hline
\end{tabular}

